\title{
Ethical Wisdom of Asia
}

\author{
Thomas Menamparampil*
}

\begin{abstract}
In this paper I would like to suggest that we build a common ground between communities when there is a perceived sense of injustice between them. My plea is that it has become imperative to add an ethical dimension to our discussion in our debates on justice. This paper is an invitation that we tap the ethical wisdom of various communities, in this case particularly those of Asia, in order to build better relationship between communities.
\end{abstract}

Keywords: Religion, Ethics, Virtues, Collective psyche

\section{When Co-Existence Becomes Difficult}

Our justice debates have made us aware of other dimensions of the problems that we are discussing and have led us to ask deeper questions. How do we live and work along with persons of other cultures who think and act differently from us? How do we deal with people who have other visions of life, other codes of conduct, other styles of relating with each other, other ways of showing respect, familiarity, approval; or dislike, disapproval, anger or resentment? How do we interact with people who have another understanding of what is right, good, polite, dignified, beautiful or appropriate? How do we join hands with neighbours of other beliefs in promoting common good and in handling problems in society, like growing violence, crime, dishonesty, AIDS, drugs? Especially when these problems are combined with perceptions of injustice in different directions?

* Apostolic Administrator of Jowai, Meghalaya, and Archbishop Emeritus of Guwahati, Assam, India 
Are there ways of transcending inter-community misunderstandings and tensions, basing ourselves on the values still surviving in communities rescued from various civilizational traditions? Can we learn to deal with each other as fellow human beings? How do we remain true to our Christian mission in the midst of such situations? Some time ago Pope Benedict XVI called for the appreciation of those values in different religions and cultures that foster civil coexistence (World Day of Peace, 1.1.2011, n.10).

Due to global commerce, mass migration and travelling habits of people, and the expanding reach of the communications network, we are compelled to live in a culturally and religiously pluralistic society in almost every part of the world. Such a situation may be looked at as an unmanageable problem or a singular opportunity for learning from other communities and profiting from the specific genius of each. In trying to draw benefit from cultural diversity lies the realistic wisdom of tomorrow. But where do we begin? Will a few more self-help books and personality development courses suffice? Or, will better self-presentation, winning manners, and improved norms of civility serve the purpose?

Or do we need go deeper and accept the truth that certain things are conducive to social growth and certain things are not, that there are things that are right that needs to be done, and there are things that are wrong that ought not to be done in view of the common good? Who will teach us about that? The people of Israel felt at certain moments that they had no prophet or teacher to guide them. The psalmist speaks of times when there was no honest person left (Psalms 12:1-2). It is in such desperate situations that new prophets arise.

May be the present uncertainty about reliable ethical norms is an invitation to our prophetic urges to exercise a sense of responsibility for the good of human society. Divine wisdom springs up in the hearts of human beings "turning them into friends and spokesmen of God" (Wisdom 7:27). 


\section{Is a Middle Way Possible?}

No doubt, there is a certain amount of pessimism in the air. The feeling is that philosophers and saints have devoted lifetimes to study and debate without resolving the issue of a universal human ethics (Dalla Costa, 1998). This is one of the problems with which the Indian mind had wrestled for centuries. In the ancient epic Mahabharata we come across characters who, unlike Greek heroes, discuss the morality of war even in the midst of the battle. Duryodhana, the evil genius in the entire narrative, is very frank in admitting, "The warrior's (kshatriya's) duty is to prevail...whether by virtuous means or not..." (Das, 2009). Most fighting men would agree with such a statement. Similar ideas would be expressed by Kautilya, Machiavelli or Thomas Hobbes. This is the logic which in India is called the logic of the big-fish-eating-small-fish.

Arjuna, the great hero of the epic, admits at one point, "The mongoose eats mice, as the cat eats the mongoose; the dog devours the cat, your majesty, and wild beasts eat the dog" (ibid).He seems to say that taking advantage of the weaker is the law of nature. There are other characters who go to the point of saying that the sacred writings (the Vedas) themselves are not helpful in evaluating what is right, that they often contradict; that even good people frequently prove unreliable. Bhishma, the wise man, finally concludes, "Dharma (uprightness) is subtle" (ibidem 46). Yudhishthira keeps questioning dharma till the very end of the story (ibidem 281). And no clear answer emerges.

Despite such pessimism when things go wrong or argument takes the wrong direction, we realize that people in different eras and civilizations have always thought that there are some things ethically right and socially becoming, while others are not. They felt convinced that there was a natural desire in human hearts to do what is right. The great Indian poet Kalidasa (5th century) referred to the 'inclination of the heart of a good person' as a reliable guide in such matters (Das, op. cit.). Manu, the Indian lawgiver, thought that satisfaction of the mind was one important criterion for evaluating moral choices (Das, op. cit.).

Even amidst many uncertainties, people today recognize the need for cultivating a sensibility and developing an attitude of 
responsibility in making moral decisions. In a globalized world, a global ethic has become necessary. We need the help of global wisdom to tame and educate global greed. This ethic should not limit itself to a new skill to be learned, but a delicate sensibility to be tenderly cultivated. It should not be left as optional to everyone. On the contrary, it should be binding; but at the same time liberating and empowering as well. For, even hard-core capitalists, who seem to be totally indifferent to spiritual realities, feel the need for the protection of law and the mutuality of contracts in order to continue their business (Dalla Costa 5). Everyone is going to benefit from shared ethical principles.

In this area there is an urgent need for collaborating across cultures and religious traditions. If Martin Luther King, Abraham Joshua Heschel, Thich Nhat Hanh could join hand together in Civil Rights and Peace initiatives, people of different beliefs and identities can share the common ethic of human dignity, human rights, and human liberation. All they have to do is to accept and respect the core ethical values common to different traditions which are to be found in various forms within various cultural heritages. Dhammapada taught, "to avoid evil, to cultivate good, and to purify one's mind-that is the teaching of the Buddha" (verse 183). The Buddha's 'Middle Way' suggested living a sane, moderate and balanced life. A missionary working in the fields of education, health or social development will need to work together with people of other faiths continually following commonly acceptable principles. When he/she works closely with them, he/she notices that there is wide common ground that can be shared, and that people are willing to cooperate.

\section{Searching for a Common Ground}

But to bring people of different traditions to a consensus on common ethical principles is not easy. To begin with, what we notice is that ethical codes are religiously and culturally embedded. ${ }^{1}$ They are part of the moral wisdom that each

1We do agree that "cultures are seldom unified, coherent, self-contained units" and that an ethnographer's writing freezes a living, developing culture to a moment of its existence. We agree too that in today's 
community has developed over a period of centuries and are as diverse as cultures themselves. They differ not only among themselves, but also among the sub-groups within them based on class, ideology, historic experiences etc. Nonetheless, convergences in moral perceptions are evident across cultures, religions, ranks and positions. In recent years inter-religious conversations have assisted mutual understanding and generated a desire for the development of an interfaith ethic. Certainly there are some broad principles that would find ready acceptance anywhere in the world. To take one example, when Bernard Lonergan suggests "Be attentive, be intelligent, be reasonable, be responsible", no one objects. But such norms are too vague to be helpful for organizing our life with its daily challenges.

pluralistic society, cultures are no more 'integrated': there is mixture, change, conflict (Miller 23). We agree further that cultures are being commodified and commercialized today than respected, when cultural items are collected, handed around and sold by people who do not belong to that culture (ibidem 70). For, respect for other cultures is not shown by displaying their symbols without knowing or achieving their meaning and context nor by adopting them, but showing how they relate with one's own culture in a healthy manner (ibiden 193). Despite all these problems, cultures retain their sturdiness and are showing their resilience today. People living in cities, uprooted from their communities, can have an exhilarating and debilitating experience at the same time (Miller 85). They feel thrilled by the novelty of new ideas and gadgets, but at the same time are drained of their spiritual resources. In this era of detraditionalization, people are steadily distancing themselves from their own inherited moral codes in the excitement about what is new. An invitation to caution is timely. People of all traditions should be encouraged to understand, re-interpret and re-appropriate their own traditions and values that retain their validity even in the changed circumstances. It is in this context we speak of pluralism which means respecting cultures, races, peoples, communities, and different visions of politics and economics. In this era of differences and uncertainties, we need cultural bridge-builders, internationalists, cross-cultural workers, cosmopolitans, and light-bearers. 


\section{Avoiding Relativism and Crass Pragmatism}

If the global ethic proposed by a dominant community is ethnocentric and self-serving, it will surely be resisted by other communities. In the same way, a vague pluralism or crass pragmatism that leads to relativism in religious faith, morality, and values, would be unacceptable. If, on the contrary, the ethical principles proposed assist people to find a common moral ground for daily living, most people would be happy to profit from them (Schweiker, 2008). In order to achieve that we ought to bring sincerity to our moral search and combine an intuitive moral sensibility and ethical alertness to the pluralistic situation in which we have to live. ${ }^{2}$

Our experience shows that moral sensitivity arises spontaneously in human hearts. Asoka (d. 232 BC), the Indian Emperor, felt 'remorse' after the Kalinga war, thinking over the deaths he had caused. His rock edicts reflect this inner agony and the concern he felt for others as a consequence. The edict XIII reads "Kalinga was conquered by His Sacred and Gracious Majesty... Thus arose His Sacred Majesty's remorse for having conquered the Kalingas, because the conquest of a country previously unconquered involves the slaughter, death and carrying away the people as captives.. This is a matter of profound sorrow and regret to His Sacred Majesty" (Smith, 1992). From that time he gave himself to the mission of promoting within his empire and in the rest of the

2Pope Benedict XVI writes, "Politics and diplomacy should look to the moral and spiritual patrimony offered by the great religions of the world in order to acknowledge and affirm universal truths, principles and values which cannot be denied without denying the dignity of the human person...It means acting in a responsible way on the basis of an objective and integral knowledge of the facts; it means deconstructing political ideologies which end up supplanting truth and human dignity in order to promote pseudo-values under the pretext of peace, development and human rights; it means fostering an unswerving commitment to base positive law on the principles of natural law" (Benedict XVI, World Day of Peace, 1.1.2011, n.12). Cicero spoke of being 'a citizen of the whole universe, as if it were of a single city'. Similarly, Diogenes claimed to be the citizen of the world, not merely of Athens or Greece. 
world an ethical order of universal significance according to the teaching of the Buddha: compassion, liberality, truth, purity, gentleness, peace, joyousness, saintliness, self-control. (ibid).

\section{Arousing a Sense of Collective Responsibility}

Everyone admits for certain that, despite differences, there can be morally decent people and rational beings and that they can learn from each other. Societies in every age and nation have respected humane and practical forms of reasonableness. For example, they have valued good judgement, friendship, loyalty, compassion, gratitude, generosity, sympathy, family affection, and the most important principle that one should never use others as a means. People of every ethnic group, political affiliation, rank or position are open to rational truths, welcome dignified codes of conduct, and retain optimism about the wisdom of the world community concerning common good. ${ }^{3}$

In spite of all this, what seems to be missing is a readiness on the part of many to take collective responsibility for persuading each other to accept at least some broad ethical norms for the common good. No wonder the situation of violence, deceit, injustice, and sexual immorality around us seems to be worsening. But if we could make a decision for collective responsibility, we would be better prepared to face the challenges of our times: e.g. for containing terrorism, assisting weaker communities, promoting the

${ }^{3}$ Yajnavalkya listed centuries ago nine virtues common to all: nonviolence, truth, refraining from theft, purity, control of senses, generosity, self-control, compassion and patience. Areas where our collective responsibility will need to be exercised in our own days are: human rights, treatment of women, family values, respect for life (questioning life-damaging technology), social ethics, environment, unrenewable resources, and stewardship over nature. We are encouraged to become actively engaged in life-enhancing services like care of children, the old, sick, and needy parents; and showing solidarity within one's own group and assistance beyond, and constantly striving to eliminate violence and deceit. Some of these are duties, some are ideals. But all are important. Universal responsibility extends to all humans, in fact to the whole of creation. 
more fragile sections in society, and insisting on honest business transactions. We are happy to do such things, not merely because of any material benefits we may derive from them, but because we value people as human beings.

\section{Consulting the Collective Psyche of Communities}

"Well then, every scribe who becomes a disciple of the kingdom of heaven is like a householder who brings out from his storeroom things both new and old' (Matthew 13:52).

People search for moral norms and ethical principles at the first instance from the insights provided by their own culture and civilization: i.e. what they have learnt from their parents, relatives, teachers, elders; from the wise men of their society, including philosophers, thinkers, religious teachers, writers, poets, artists. What such persons have thought and taught have gone into the collective psyche of their community, and remain there as a ready resource to assist them in their effort to shape their destiny. That remains as the first resource of every community. At the second instance communities look for wisdom from the cultural and historic experiences of other communities in the neighbourhood and beyond. In pluralistic societies this has become a necessity. Pope Benedict XVI says, “...new generations can build on the knowledge and experiences of those who went before, and they can draw upon the moral treasury of the whole of humanity" (Spe Salvi 24).

Anyone who has to deal with people of another culture/religion/civilization will have to get familiar with the psychological/cultural/spiritual assets of their culture if they want to be effective. A missionary diligently studies the cultural traditions and value-systems of others, so that he/she can be helpful in dealing with current problems, like violence, corruption or unethical practices in the society at whose service he is. In this effort he will have to go beyond invoking prevalent civil laws and UN declarations. If, going further, he refers to their religious and cultural traditions, their wise men and their sacred writings, his words will have greater convincing power. A person like Ayatollah Khomeini may be more easily persuaded by respectful references to Islamic tradition than to international law. 
Christian teachers like Justin and Clement of Alexandria, wanting to introduce the Christian faith to the people of Hellenic background used categories from their traditions that would be intelligible to them. When we want to evoke the good will of any person or a community, the most intelligent thing to do is to consult the collective psyches and consciences of those communities and profit from the values cherished in their cultures and civilizations. In this paper we shall identify a few values cherished among Asians of various origins: Altruism, a sense of community, social virtues, respect for nature, uprightness in public life, and religiosity. Even though these values are under threat in our present day under secularizing pressures, they remain deeply rooted in Asian civilizations.

The following reflection is not an evaluation of the respective merits of different religions, but an effort to tap the common ethical resources of humankind for the common good. They belong to the whole of humanity.

\section{Love, Altruism}

Love for others stands at the heart of all ethical codes. Every culture has some way of saying that we ought to do to others what we would like others to do to us. This is a powerful message in an age of intense cultivation of self-interest and absolute commitment to profit-making. "Not one of you is a believer until he loves for his brother what he loves for himself" (Islam, Forty Hadith of anNawawi 13). "A man should wander about treating all creatures as he himself would be treated (Jainism, Sutrakritanga 1.11.33). "Try your best to treat others as you would wish to be treated yourself" (Mencius VII.A.4). Such precepts are very close to Christian teachings.

Confucius taught, "Persons of humanity are like this: wanting to develop themselves, they also develop others; wanting to achieve things themselves, they also allow others to achieve what they want (Analects 6.28.2-3). "Be solicitous of others, be understanding towards others" (Analects 6.12.22). Tzu-Kung asked, "Is there one word by which one may live one's entire life?" The master said, "Isn't that word 'consideration'? Do not impose on other people 
anything you yourself dislike" (Analects 6.15; 23). "To regard everyone as a very important guest, to manage the people as one would assist at a sacrifice, not to do to others what you would not have them do to you" (Analects15.23). These are precious messages even today. The Koran says "Give to the near of kin their due, and also to the destitute and to the wayfarers" (Surah 17).

Leviticus 19:18 said, "You shall love your neighbour as yourself". Jesus taught "Whatever you wish that men would do to you, do to them" (Matthew 7:12). He insisted we must go beyond what is due, even beyond what the other person expects from us. "When a man takes your coat, let him have your shirt as well" (Luke 6:29). He tells us not to entertain even a harsh thought, not to use a hard word; to take the initiative for reconciliation even in cases when it is the other person who has taken the initiative for quarrel (Matthew 5:22-23). He proposes that we invite the unjust aggressor to do even more injustice to us, offering him the other cheek (Matthew 5:39). And after that he asks us to love him, and continue to love him still when he continues to harass and persecute us, since God himself loves him (Matthew 5:44). This is the teaching that Mahatma Gandhi tried to take into the political field.

\section{Preserving a Sense of Community: Within Family, Community, Humanity}

According to many critiques of Modernity, the type of individualism it has fostered has not promoted a style of communal life that will help human flourishing. We agree that democracy and the rule of law, re-distribution of wealth, and equality of women are important. But equally important is a sense of community in our times. In Asian traditions, rights are attached to duties and obligations (Sardar, 1998). Those who claim the former must accept the latter as well.

Affirmation of community loyalty runs right through much of Asian literature. "Meet together, speak together, let your minds be of one accord. . . . May your counsel be common, your assembly common, common the mind, and the thoughts.... Let your aims be common, and your hearts be of one accord, and all of you of one mind, so you may live well together" (Rig Veda10.191.2-4). "Let us 
have concord with our own people, and concord with people who are strangers to us....May we unite in our minds, unite in our purposes, and not fight against the divine spirit within us" (Atharva Veda 7.52.1-2). The Koran re-echoes similar sentiments, "The believers indeed are brothers; so set things right between your two brothers, and fear God; haply you will find mercy" (Koran 49.10). Finally, Mishnah urges, "Separate not yourself from the community" (Mishnah, Abot 2.4).

Family values were deeply cherished in Asia. A Buddhist document says, "Supporting father and mother, cherishing wife and children and a peaceful occupation; this is the greatest blessing" (Sutta Nipata 262). The Jains teach, "Natural mildness should be there in the family" (Tattvartha Sutra 6.18). Again, "Lord, give us joy in our wives and children, and make us models for the God-fearing" (Koran 25:74). South and East Asian families were usually monogamous. The Chinese family bonds are traditionally among the strongest in the world. Confucius taught absolute solidarity within the family. He affirmed, "When brothers live in concord and at peace, the strain of harmony shall never cease" (Doctrine of the Mean 15.2-3). The following values have been diligently cultivated in Chinese society down the centuries: filial piety, care of the elderly persons, joint ownership (Bell \& Chaibong, 2003). Confucianism has given rise to communitarian cultures in Korea, Vietnam and other countries; which lay stress on social morality, community harmony, and state benevolence. The ethic of mutual help has served as bond among student groups and social activists, providing unity of purpose, mutual encouragement and support. (ibid). Communal ethic is particularly strong among the rural farming classes.

But what is most outstanding in Asia is a universal outlook that embraces the whole of humanity. "Consider the family of humankind one" (Jainism, Jinasena, Adipurana). "Let all mankind be one sect" (Sikhism, Adi Granth, Japuji 28, M.1, p.6). Thinkers like Mahatma Gandhi and Tagore, spoke for the human race as one, as did Buddha, Asoka and others in their times.

Christians look to the Bible for their inspiration. Traditional family and community values are deeply rooted in the biblical tradition. The fourth commandment says, "Honour your father and your 
mother" (Exodus 20:12). Respect for elders is taught, "You shall rise before the aged and show deference to the old" (Leviticus 32). Togetherness and harmony are strongly urged. "How wonderful it is, how pleasant, for God's people to live together in harmony!" (Psalms 133:1). Prayers keep the community together. "My house shall be called a house of prayer for all the people" (Isaiah 56.7). Jesus prayed for unity among his followers, "I do pray not only for them, but also for those who believe in me because of their message. I pray that they may all be one" (John 17:20-21). He warned them against divisions, "Any country that divides itself into groups that fight each other will not last very long. And any town or family that divides itself into groups which fight each other will fall apart" (Matthew 12:25). Jesus is the bond among his followers, "For where two or three come together in my name, I am there with them" (Matthew 18:19-20). "You are all one in Jesus Christ" (Galatians 3:28).

\section{Cultivating Social Virtues}

Abstention from causing injury to any living being and inconveniencing any person is a central teaching in all Asian traditions. Irrespective of caste and creed, the following virtues are held in high regard: patience, truthfulness, restraint, purity, liberality, self-control, not to kill, obedience to one's teachers, sympathy, straightforwardness, freedom from covetousness, freedom from anger (Van Voorst, 1994). In the Bhagavad Gita Krishna teaches, "Fearlessness, purity, determination in the discipline of knowledge, charity, self-control, sacrifice, study of sacred lore, penance, honesty; nonviolence, truth, absence of anger, disengagement, peace, loyalty, compassion for creatures, lack of greed, gentleness, modesty, reliability; brilliance, patience, resolve, charity, absence of envy and of pride; these characterize a man born of divine traits" (Bhagavad-Gita 16:1.4). Asian religions teach modesty and restraint. Mahatma Gandhi taught Ahimsa, the Dalai Lama compassion.

Confucian humanism, after being marginalized by the Left (Mao) and the Right (Lee Kwan Yew) for over a generation, is returning to Chinese public life again sturdier than ever before. The Confucian emphasis is on moral cultivation: cultivation of humanity, sense of 
fellowship, fostering of social values. Noble-minded persons should take as much trouble to discover what is right as lesser men do to discover what will pay (Analects IV.16). Confucius insists on the moral education of intellectual leaders. It must be admitted that the humanistic and liberal emphasis in Confucianism has led to fairly egalitarian forms of development in East Asia.

The genius of Lao Tzu consists in seeing the advantage of allowing natural processes their normal course, whether they be in society or in nature. He invites you to act like water, yielding, fitting into corners and crevices. And yet water holds energy, generates power. Taoism suggests you to recognize the unpredictability of the spontaneous development of things, not to insist too much on prearranged approaches. The Tao does not impose, interfere, meddle; allows things to develop and flourish, each according to its nature.

When Taoism insists on non-action, it means really non-interfering. When the Tao Te Ching insists on emptiness, nothingness, the emphasis is on the rejection of the 'Big Ego' to which all are tempted (Burke, 1996). "The best man, in his heart he loves what is profound. In his associations, he loves humanity. In his words, he loves faithfulness. In government, he loves order. In handling affairs, he loves competence. In his activities, he loves timeliness" (Lao Tzu) (Kessler, 2000). "He does not boast of himself; therefore he was given credit. He does not brag; therefore he can endure for long" (Lao Tzu) (ibid). The Koran too teaches norms of social obligation to each other; it insists on humility.

Care for the poor is a central message in most civilizations "When you harvest your fields, do not cut the corn at the edges of the fields, and do not go back to cut the ears of corn that were left. Do not go back through your vineyard to gather grapes that were missed or to pick up the grapes that have fallen; leave them for poor people and foreigners (Leviticus 19:9-10).

The Bible teaches, You shall not murder, You shall not steal (Exodus 20: 13). You shall not defraud your fellow beings. You shall not commit robbery. The wages of a labourer shall not remain with you until morning (Leviticus 19: 13). When a stranger resides with you in your land, you shall not wrong him (Leviticus 19:33). “Cease to do evil. Learn to do good. Devote yourselves to justice. 
Aid the wronged. Uphold the rights of the orphan. Defend the cause of the widow" (Isaiah 1:17).

\section{Probity in Public Life, Honesty}

"Do not cheat anyone by using false measures of length, weight or quantity. Use honest scales, honest weights, and honest measures" (Leviticus 19:35-36). In an era when corruption is moving into the highest places - governments, bureaucracies, legislatures, judiciary, law-enforcing machinery, pollution-controlling agencies, customs departments, immigration offices, official and open markets - the above message from Leviticus is most relevant. Fake goods of every kind are on sale; duplicate goods of every variety are available: books, DVDs, imitation machinery with substandard parts; adulterated medicines, spurious drugs; endangered species, human beings (women for sex, children for sweatshops), human corpses, live organs (like kidneys) for transplant; even machine guns, and rocket launchers! (Naim, 2006). There are pirated copies of classics, of bestsellers, popular music; whatever can be copied or imitated is available.

The globalized world provides the anonymity and distances that the illegal traffickers need to keep their business invisible. Internet contacts have furthered their possibilities. The deregulation policy that most governments have adopted has weakened the lawenforcing machinery, and illicit traders keep hopping between jurisdictions. International terrorism follows the track of international illicit trade, using the same techniques and facilities. Those who deal in illegal arms keep backing regular criminals, terrorists, urban rioters, political protesters, communal radicals, and secessionists.

It was when corruption began growing rampant, that Chinese Communist leaders decided to return to Confucian values with the intention of renewing their society. Confucius taught that one should pursue justice, not profit. Likewise Taoism teaches "Be honest like Heaven in conducting your affairs" (Taoism, Tract of the Quiet Way). "There is no misfortune greater than being covetous" (Tao Te Ching 46). Master Tseng said, "Every day I 
examine myself...In intercourse with my friends, have I always been true to my word?" (Analects 1.4).

Centuries ago the Upanishads had taught "Truth alone triumphs and not untruth" (Mundaka Upanishad III,1,6). Kabir used to say "Better to be cheated than cheat others". And Swami Vivekananda believed, "Society must be moulded by truth". Islam threatens severe punishments for the wrongdoer. "Lo! Those who devour the wealth of orphans wrongfully, they do not but swallow fire into their bellies, and they will be exposed to burning flame" (Koran 4.10). "Keep your promises; you are accountable for all that you promise...give full measure, when you measure, and weigh with even scales" (Surah 17).

There is abundant teaching in the Bible about honesty, truthfulness and uprightness: "Do not cheat anyone by using false measures of length, weight or quantity. Use honest scales, honest weights, and honest measures" (Leviticus 19.35-36). Be honest (Leviticus 19:15), use honest scales (Leviticus 19:36), serve in integrity (1 Kings 8:3), do not accept bribes (Exodus 23:8; Proverbs 17: 8, 28:21); God does not tolerate fraud or partiality (2 Chronicles 19:7). It is a great mission today to work for probity in public life.

\section{Respect for Life, for Nature, Environmental Stewardship}

Reverence for life at every stage of its development is a theme that runs right through the heart of every Asian tradition. As it is well known, the Jains were the most radical in their defense of life, possibly in the face of violent invaders, decimating indigenous races, and taking away animal lives in lavish Vedic sacrifices, damaging nature by extending farming areas into the territories of native communities. Buddhism was true to the same tradition of promoting peace. Nonviolence today constitutes a core value in Hindu tradition. The Asian soul instinctively recoils before abortion, euthanasia, excessive tampering with nature in human reproduction, violence to animal and vegetative life.

For the Vedic Aryans, nature was the symbol of the divine: sun, wind, ocean, earth, soil, mountains, forests, springs. "O Mother Earth! Sacred are thy hills, snowy mountains, and deep forests. Be kind to us and bestow upon us happiness. May you be fertile, arable, and 
nourisher of all. May you continue supporting people of all races and nations. May you protect us from your anger (natural disasters). And may no one exploit and subjugate your children" (Atharva Veda, 12.1.11). The farmer prays fervently that the hurt he inflicts on nature may speedily be healed. "Whatever I dig up of you, O earth, may you of that have quick replenishment" (Atharva Veda, 12, 1.64). "The earth is the mother, and I the son of the earth" (Atharva Veda 12.12). "What, O earth, I dig out of thee, quickly shall that grow again: may I not, $\mathrm{O}$ pure one, pierce thy vital spot, and not thy heart" (Atharva Veda 12.35). The Rig Veda has in places phrases like "O knife, do not hurt him", “O stones, listen”.

The Yajnavalkya Smriti says, "If any man has cut a tree, a thicket, a creeper or a shrub, he should recite one hundred Vedic verses. If a man is guilty of recklessly cutting a medicinal plant, he should subsist on milk for one day and follow a cow" (2.276). Herbal medicines were very popular. "The earth is a garden, the Lord its gardener, cherishing all, none neglected" (Sikhism, AdiGranth, MajhAshtpadi, 1, M.3, p 118).

Emperor Asoka writes, "I have ordered banyan trees to be planted along the roads to give shade to men and animals. I have ordered mango groves to be planted. I have ordered wells to be dug every half a mile, and I have had many watering stations built for the convenience of men".

We can never forget that the Buddha attained enlightenment under a tree. Wise men in India those days retired to the forest in order to meditate. The Himalayas were a sacred destination. Asia's ancient educational centres were Ashrams which were always located on the margin of forests. Tagore's Shantiniketan sought to recapture this spirit of closeness to nature. For him, trees were prayers and they spoke about God. "Silence, my soul," he said, "these trees are my prayers". And he went on, "I asked the tree, speak to me about God, and it blossomed". The Psalmist expresses similar sentiments in many places. He invites the trees of the forest to shout for joy (Psalms 96:12).

Other Asian traditions too emphasize the connectedness of things. "No creature is there crawling on the earth, no bird flying with its wings, but they are nations like yourselves (Koran 6.38). "Do not let 
man destroy Nature. Do not let cleverness destroy the natural order" (Taoism, Chuang Tzu 17). In the context of the recent epidemics that have broken out among cattle, sheep, chickens, fish, dolphins, we need to take a warning. We need to exercise stewardship on behalf of all living things. "Rear them, but do not lay claim on them; control them, but never lean upon them; be their steward, but do not manage them" (Tao Te Ching 51). Lao Tzu had said, centuries ago "The best man in his dwelling loves the earth".

How good to remember that "The world and all that is in it belong to the Lord; the earth and all who live on it are his" (Psalms 24:1), that we need to take care of vegetation. Wait for a period of time before you eat fruits from the tree you have planted, Leviticus 19:23-25 said, "When you come into the land of Canaan and plant any kind of fruit tree...in the fifth year you may eat the fruit. If you do this, your trees will bear more fruit".

What about rights of all life forms which are all brothers and sisters, as Francis of Assissi thought? And does not salvation include all sentient things, does not all creation in fact groan for its deliverance (Romans 8:22)?

\section{Religiosity, the Sense of the Sacred}

Amazingly, when many of the developed parts of the world have been fast secularizing, Asians as a whole have fiercely held on to their faiths. This religious seriousness is to be considered a common spiritual asset, not only for Asians, but for the whole of humanity. Pope John Paul II looked at this phenomenon with interest and respect.

Z. Sardar affirms that the gulf that exists today between the radical secularism in some regions of the world and the religiosity in other regions is glaringly great. The present-day emphasis on 'rights' needs a foundation. That foundation in the east is provided by religion. He proposes for postmodern times a return to tradition, meaning an effort for 'sustaining the values and axioms of a civilization'. He rejects the amorality, relativism, and nihilism of postmodern culture (McGuigan, 1999). 
India's heroes have always been people with spiritual depth (the Buddha, Mahatma Gandhi, Tagore, Dalai Lama, Mother Teresa), not conquerors, millionaires or sportsmen. Asians admire genuine intellectuals, not mere rationalists. They willingly listen to persons who have had a religious intuition and speak with spiritual unction, and who are not mere sectarian or parochially minded zealots. Adherents to non-Christian religions have loved to read Christian books of some depth: the Bible, the Gospels, the Imitation Christ, Confessions of St. Augustine, the writings of St. Teresa of Avila and St. John of the Cross. Leaders who are intellectually bent, eager to share knowledge, and are inclined to contemplation, reflection, mysticism and renunciation always earn the respect of Asians and win a hearing.

Asians have amazingly retained a great Sense of the Sacred. It is a precious value in a rapidly secularizing world to be preserved and fostered. They respect religious persons, gladly take part in religious events, make religious journeys (pilgrimages), keep reciting sacred words. Those words are considered eternal (Radhakrishnan, 1982). Asians hold in reverence everything that is symbolic of the divine: sacred places, sacred words, rituals, chants, practices, traditions, objects, teachings, laws, values. When we play with religious ceremonies or trivialize sacred symbolisms or improvise shabby liturgical formulations, we go directly against the religious instincts of the Asians. Asians value silence, renunciation, and a message given with profound conviction. Detachment is considered a sign of genuineness.

\section{Models Inspire, Prove Possibility of Imitation}

Arguments based on religious texts alone may not carry conviction in isolation. They must be put in relationship to human wisdom as understood in different cultures. They must also be counterchecked with the criteria that are widely considered valid in our times ${ }^{4}(1)$.

${ }^{4}$ Amartya Sen, a Nobel Prize winner, suggests a few norms in his recent book The Idea of Justice that can be helpful in our way of life together. He urges us to accept the possibility that another theory than our own may have the features of impartiality, fairness, being unbiased and dispassionate (Sen 2009:57); to take note of other people's point of view, 
When many approaches combine, the central message goes through and makes an appeal. In this way cooperation in the area of ethical reflection becomes possible, while maintaining at the same time each one his/her own religious identity. May be Asians will be more open to learn from metaphors than syllogisms, living models than logical arguments. They look with admiration at inspiring precedents even in other traditions. The figures of persons like Mother Teresa or John Paul II touched the hearts of people more than apologetics in self-defense or efforts in selfadvertisement. They were models of self-giving and egolessness, and exemplified a flaming spirit. Thus they emerged as persuasive agents of social change and wellbeing.

Many people think that persons of high moral caliber hold up unrealistic ideals before others and that these ideals do not correspond to the way that the real world works. The alternative models they place before us maybe extreme pragmatists like Richelieu, Metternich or Bismark in the past or Kissinger in our times, who were specially skilled in what is called realpolitik. But men like Dag Hammarskjold, Mahatma Gandhi, Martin Luther King, Lech Walesa, Vaclav Havel, Albert Luthuli, Alexander Solzhenitsyn, Nelson Mandela, Desmond Tutu, Aung San Suu Kyi did not seem to be unrealistic in their approach to the mighty problems they had in hand. They finally achieved what they set out to do. A missionary, for all his/her great ideals, lives close to

welcome information and remain open-minded in public dialogue (ibidem 43), to recognize the fact that at a given time we are confronted with a plurality of competing principles, making it necessary for us to subject opinions repeatedly to serious scrutiny and ourselves to selfscrutiny using a variety of these competing principles and different perspectives (Ibidem 183). Global voices on any issue can set us thinking (ibidem 408). A view from a distance always puts things in perspective. For example, Sen asks how would lynching of miscreants in America appear to other communities, or the stoning of adulterous women in Afghanistan, or abortion of female foetus in India, or capital punishment in China (ibidem 405), or blasphemy laws in Pakistan? Now that human interdependence is growing, it has become important to listen to the consciences of other cultures and to study the moral codes developed in other societies. 
human reality and knows how to adopt a realistic approach to concrete problems in society.

Let us look at the example of Mahatma Gandhi who drew from diverse traditions. He kept learning from Christianity and showed respect to the Islamic tradition. He was open to all truths while being attentive to differences. He was inclusive (Schweikerop. cit.) and affirmed his oneness with humanity. He was Hindu in the cultural sense, but not sectarian. He took images from his own religious tradition and from the Jain teachings on nonviolence, but adapted them to the political and social goals he had chosen. His concept of ramarajya sounded much like an interpretation of the Christian concept of the 'kingdom of God'. His idea of satyagraha, adherence to the truth, meant in fact loyalty to everything that was upright and good. For him Ahimsa was not mere passive nonviolence but active engagement for the alleviation of suffering and the transformation of society (ibid). He sought to achieve liberation, moksha, by fulfilling his life-mission in the political field. He looked at this commitment to his duty as a spiritual struggle. He generally took care to express himself in widely acceptable vocabulary, and therefore his words had convincing power.

\section{A World in Crisis is Looking for Answers}

We need prophetic persons to take in hand the problems that confront us today. We notice that not only are religions in crisis, but also cultures and civilizations, including the present day's secular civilization itself. The following are some questions that come to our mind in this critical situation. What happens to humanity when, too many of us, having rejected religion as an illusion, have become passive consumers of other types of illusions? What happens when we suffer not only from a loss of religious faith, but of humanity? What happens when materialism replaces social health, and the home values of cooperation, decency, kindness, hospitality are no more handed on to the next generation?

There was a time when companies and governments used to leave ethics to families, teachers, churches, community and religious leaders. But nothing like that happens any more. There is less of 
ethical content in teaching, less of traditional values in the handing on of heritages, and we forget that our duty to love our neighbour includes also our obligation to 'love our children and grandchildren as we love ourselves'. And we forget that this love is expressed not by being concerned about non-renewable resources only, but also about the transmission of the gains of culture and civilization (ibid).

Religion, which used to shape values within communities in earlier times, is fast becoming no more than a nostalgia for the past in many places of the world. It expresses itself in curious ways in different places: in a frantic search for 'rare experiences', the ransacking of the world's cultural and spiritual treasures torn from their contexts, the commodification and irreverent use of cultural and religious objects. Some turn religion into mere therapy and others make salvation a search for mental health (Wuthnow, 1995). Others, on the contrary, go radical in the direction of fundamentalism. As the global economy keeps growing, humanity is not growing as a community. No code of conduct is developing in the area of competing self-interests.

The consequences are evident. Sublime values are no more visible in public life. Aggressiveness of the market competes with aggressiveness of arms. Egocentric lust for money and power dominates the world scene. Heroes/heroines of service are hard to find, but workaholic billionaires keep increasing in number. Their life ambition is to imitate Attila the Hun and Genghis Khan the Mongol in wiping out business competitors. The wars for colonies of the previous centuries have been replaced by wars for the market. The vocabulary of struggle and fighting for real and imagined rights fascinate the rising generations. Efforts for progress and development have come to be described only in terms of adversarial relationships, ruptures and discontinuities, not of collaboration, common endeavour and sharing of ideas, heritages and resources.

Modernity has promoted justice not moral values. It is evident that claims for human rights alone do not exhaust the comprehensive requirements of morality. 
When the force of the Communist ideology stood over the world as a threat, people ignored or tolerated the sophistries of the capitalist ideology. Today the deceptive ways introduced into society by that elusive theory are becoming evident. Aggressive profit-makers play the same games that totalitarian societies played earlier. For example, Marxism criticized religion, but produced a new type of 'religion' that ended all criticism. Under the present ideology of money-making, criticisms of vested interests are similarly marginalized or muffled in the media. But religion is attacked, religious personnel persecuted, and in some countries religious symbolisms are being removed from public places. ${ }^{5}$ At the same time, atheism is promoted and anti-religious campaigns are encouraged. When such things happened under communist regimes, the whole world seemed shocked and there was a global reaction. Today unfairness to believers seems to be considered the most intelligent and fashionable way of behaving.

There was a time when the bureaucratic impersonality of the totalitarian states was considered a horror. But today multinational corporations have developed the skill of remaining anonymous and impersonal to everyone, workers and customers included. There is no accountability to any known persons. Robert Bellah calls it 'market totalitarianism'. Citizens are selling off their personal dignity for a small pay-raise and disposing off their most valued cultural heritage for trivialities which they think add to their comfort. People are blinded by the brilliant performance of some financial wizard, to whom gradually everything becomes legitimate. It gives the impression that there is no law beyond economic success, which has emerged as the summum bonum amidst human goals and suprema lex among moral principles. But we know that there is balance in the human processes and it asserts itself ultimately even after chaotic social movements and uncontrolled aberrations. The global market will be defeated by its own moral inversions and excesses (Dalla Costa 61).

5 (1)Pope Benedict XVI spoke recently about the West rejecting its history, religious symbols, and being embarrassed about its identity... giving a sign of hatred and prejudice, rejection of their spiritual heritage, and Christian roots (Benedict XVI, World Day of Peace, 1.1.2011, n. 13). 
The values proposed by the old cultures cannot die out totally. We can already see their defenders going to the extent of launching 'culture wars'. Cultural energies that have been suppressed or marginalized by global materialism will show their strength in different places. However, they need not take to violence; for, cultures have an inner strength of their own. "Made up of history and experience, memory and expectation, cultures have their resiliency, even rigidity of personality" (Dalla Costa 220). Anthropologists tell us that cultural traditions play a greater role in our life than even beliefs. The truth of this insight becomes evident when we watch how Japan took pains to ensure civilizational continuity while modernizing. China and India are trying to do the same. It is in this area of civilizational sensitivity and cultural promotion that religious leaders can make a significant contribution. They can join hands together for preserving their own respective cultural heritages. In doing so, they are in fact assisting to rescue some of the central values common to humanity. For example, we begin to realize that being singularly selfish is selfdefeating. 'Self-interest, self-rights and self-preservation involve and are even advanced by self-sacrifice, self-discipline and selfgiving" (ibidem 105).

"The public space which the international community makes available for the religions and their proposal of what constitutes a "good life" helps to create a measure of agreement about truth and goodness, and a moral consensus; both of these are fundamental to a just and peaceful existence. The leaders of religions, thanks to their position, their influence and their authority in their respective communities, are the first ones called to mutual respect and dialogue" (Benedict XVI, World Day of Peace, 1.1.2011, n 10).

With all the present uncertainties, the world is looking for persons invested with moral authority; not those who claim it as though it is theirs by right, but those who, even from a position of weakness, know how to persuade others to do what is right. That is true authority. What they ask is simple: accept what is true and good. They argue for the truth not merely with their words, but with their life and work. Since they are credible personalities, what they say becomes credible. People generally listen to persons of good judgment who strive to make only acceptable proposals; are 
knowledgeable, sensitive, and decent; are interpreters of sound ethical traditions; speak to people's interests, show esteem to their values and tastes, seek to understand others' way of doing things; and, more than anything else, who seem to love and respect people.

In modern times moral philosophy has been proposed to replace religious ethics. It should not mean each one deciding for himself what is suitable to him. With due respect to various forms of moral wisdom proposed in secular contexts, they ought to recognize the contribution that religious principles make to society. Pope Benedict XVI, speaking on the World Day of Peace on January 1, 2011 referred to the constructive role that believers have played for the promotion of ethical values in the political sphere and for the common good. Religion reinforces social cohesion, integration and solidarity. Persons like Mahatma Gandhi and Martin Luther King have been credited for their gift of persuading others of what is best in difficult circumstances, because they appealed to people's consciences as Jesus did.

Yudhishtira, the hero of the Indian epic Mahabharata, says it is not reason alone that points to upright behaviour (dharma) nor holy sayings; dharma rather is hidden in a cave" (Das, op. cit.), the cave of one's heart. Deep religiosity that one cultivates in one's heart generates principles and values that enrich the ethos of a people. It speaks directly to the conscience and mind of a community, calls for moral transformation, encourages practice of virtues, as members of a loving human family (Benedicts XVI, World Day of Peace, 1.1.2011, n.9). Seneca said, becoming good is an art. It is precisely this sort of art that has a hidden link with mysticism and opens a door to the Ultimate reality.

A Christian is invited to take seriously the challenge which Christ has placed before humanity: be like the Father in heaven to whose goodness there is no limit. "There must be no limit to your goodness as your heavenly Father's goodness knows no bounds" (Matthew5:48). At this point we reach a climax. Beyond this we cannot go. We place the image of the Father before us for imitation. Henceforth our life is to be shaped after Him, Who is 'perfect'. His unbounded goodness is a compelling force. It does not stand on the way to progress, freedom and an optimistic view of human possibilities; in fact, it furthers them. For, human intelligence attains its utmost 
potential, not when it splits the atom or explores the distant skies, but when it discerns what is good and what is evil, when it makes a correct ethical choice. It is then that the human person becomes most like unto God. The image of the Father that is in him reveals itself. It is precisely then that the human person becomes fully human and capable of showing a path to the future to his fellow-beings. Pope Benedict XVI says, "The love of God is revealed in responsibility for others" (Spe Salvi 28).

\section{References}

Bell, Daniel A. \& Chaibong, Hahm. Confucianism for the Modern World. Cambridge: Cambridge University Press, 2003, pp 16

Ibid pp 10-11

Burke, T. Patrick. The Major Religions. Malden: Blackwell Publishers, 1996, pp 135.

Dalla Costa, John. The Ethical Imperative. Reading: Addison-Wesley, 1998, xii

Dalla Costa, op. cit 5

Dalla Costa, op. cit 61

Dalla Costa, op. cit 220

Das, Gurucharan. The Difficulty of Being Good. New Delhi: Penguin Books India, 2009, pp 14

Ibid pp 15

Ibid pp 48

Ibid pp xliii

Kessler, Gary E. Ways of Being Religious. California: Mayfield Publishing Co, 2000. pp 301

Ibid 302

McGuigan, Jim. Modernity and Postmodern Culture. Buckingham: Open University Press, 1999, pp 91

Naim, Moses. Illicit. New York: Anchor Books, 2006, pp 2

Radhakrishnan, Sarvapalli. The Culture of India. Calcutta: The Ramakrishna Institute of Culture, 1982. pp 299.

Sardar, Z. Postmodernism and the Other: The New Imperialism of Western Culture. London: Pluto, 1998. pp 65

Schweiker, William. The Blackwell Companion to Religious Ethics. Malden: Blackwell Publishing Ltd, 2008, pp 135

Ibid 343

Ibid 360

Ibid 67

Ibid 515 
Sen, Amartya. The Idea of Justice. London: Penguin Group, 2009.

Smith, Vincent. The Oxford History of India. New Delhi: Oxford University Press, 1992, pp 119

Van Voorst, Robert E. Anthology of World Scriptures. California: Wadsworth Publishing Company, 1994, pp 37

Wuthnow, Robert, ed. Rethinking Materialism. William Eerdmans Publishing co., Grand Rapids, 1995, pp 52 